\title{
PENGGUNAANAPLIKASI BLACKBERRY MESSENGER (BBM) SEBAGAI MEDIA UNTUK EVALUASI MAHASISWA
}

\author{
Toni Kus Indratno \\ Pendidikan Fisika, Fakultas Keguruan dan Ilmu Pendidikan, Universitas Ahmad Dahlan \\ Email : tonikus@staff.uad.ac.id
}

\begin{abstract}
Abstrak
Penggunaaan teknologi ke dalam setiap sendi kehidupan mutlak diperlukan untuk masa sekarang ini. Hampir setiap orang mempunyai smartphone untuk mendukung aktivitasnya sehari-hari. Akan tetapi penggunaan teknologi yang serba canggih apabila tidak diimbangi dengan kearifan, akan berdampak pada hal negatif saja, bahkan mengaburkan fungsi penting dari teknologi itu sendiri. Blackberry messenger atau yang lebih dikenal BBM merupakan satu dari sekian banyak aplikasi yang hampir pasti ada di setiap smartphone. Sisi kecepatan transfer data dan kemudahan berkirim berkas (file) menjadi daya tarik tersendiri dari aplikasi ini. Pemanfaatan BBM untuk mendukung proses evaluasi mahasiswa telah dilakukan pada penelitian ini. Mahasiswa diberikan soal kuis untuk dikerjakan pada dini hari (mulai Pkl. 03.00 s.d. 05.00), hasil pekerjaan mahasiswa dikirim menggunakan aplikasi BBM dalam bentuk gambar. Penelitian ini menggunakan desain penelitian studi lapangan. Jenis penelitian ini adalah deskriptif kualitatif. Teknik pengumpulan data menggunakan dokumentasi. Hasil penelitian menunjukkan bahwa mahasiswa merasa lebih leluasa dalam mengerjakan kuis, mereka bisa mengerjakan sesuai gaya belajar masing-masing, tidak dibatasi oleh ruang dan suasana yang menegangkan. Waktu pengerjaan dini haripun membawa pengaruh positif, dengan pikiran yang masih segar, mahasiswa bisa lebih optimal dalam mengerjakan kuis.
\end{abstract}

Kata kunci: $\quad$ BBM, evaluasi, pemanfaatan teknologi

\section{Pendahuluan}

Penggunaan teknologi yang mutakhir dalam kehidupan sehari-hari sudah merupakan hal yang lumrah. Contoh yang paling nyata adalah migrasi penggunaan telepon genggam ke telepon pintar (smartphone). Hampir setiap orang sekarang sudah menggunakan smartphone untuk mendukung aktivitasnya. Bahkan terkadang satu orang bisa memiliki smartphone lebih dari satu.

Bahkan salah satu laman yang konsen dalam penulisan artikel tentang teknologi (Millward, 2014) (NN, 2015) menyebutkan bahwa pada tahun 2018 pengguna smartphone di Indonesia lampaui 100 juta pengguna dan terbanyak keempat dunia.

Tujuan diciptakannya smartphone adalah agar dapat membantu kehidupan sehari-hari manusia dalam beraktivitas (Widhyatmoko, 2011). Dikalangan pebisnis, piranti ini mutlak dibutuhkan, terutama untuk mendukung kebutuhan akan akses informasi yang serba cepat.
Data yang dilansir oleh CNN Indonesia tentang demografi pengguna internet $\mathrm{di}$ Indonesia, menyatakan bahwa $85 \%$ masyarakat menggunakan smartphone untuk mengakses internet, 49\%-nya adalah usia remaja (18 s.d. 25 tahun) (Fajrian, 2015). Hal yang senada juga diungkapkan Hesyta (Hestya, 2012) yang menuliskan bahwa pengguna smartphone dikalangan remaja mencapai $58 \%$.

Media sosial merupakan hal yang paling banyak diakses oleh pengguna smartphone (Abadi, 2013). Salah satunya adalah Blackbarry Messanger (BBM). Penggunaan BBM dikalangan remaja lebih untuk mengirimkan pesan (chatting), berbagi foto profil (DP), bahkan status selayaknya facebook.

Ada beberapa keunggulan BBM dibandingkan dengan media sosial lainnya. Antara lain keprivasian pesan dan kecepatan transsfer data. Hal inilah yang biasa dimanfaatkan oleh para bebisnis, untuk saling bertukar data. Pada penelitian ini, BBM coba 
dimanfaatkan sebagai sarana evaluasi (kuis) mahasiswa.

Kuis merupakan sarana evaluasi untuk mahasiswa selain Ujian Tengah Semester (UTS) dan Ujian Akhir Semester (UAS). Kuis biasanya diselenggarakan oleh dosen untuk menguji pengetahuan mahasiswa per topik pembahasan. Dengan kuis bisa diketahui seberapa paham mahasiswa dalam tentang topik yang disampaikan dosen.

Kuis selama ini diadakan dalam kelas, pada jam kuliah. Kuis dikerjakan dalam suasana yang "menegangkan". Dengan jarak antar mahasiswa yang jauh, tidak boleh tengok kanan-kiri, posisi duduk yang tegap, dll. Layaknya Ujian Nasional. Kondisi semacam ini, secara psikologis bisa mempengaruhi kemampuan mahasiswa. Sehingga kadang kondisi yang terukur bukan kondisi yang sebenarnya. Kadang ada mahasiswa yang sebenarnya mempunyai kemampuan tinggi, tapi karena adanya situasi semacam ini dia menjadi grogi, sehingga kemampuan yang sebenarnya tidak muncul.

Setiap mahasiswa pasti mempunyai gaya belajar yang berbeda-beda. Ada yang suka sambil mendengarkan musik, sambil lesehan, berbading, dsb. Kondisi semacam ini tidak mungkin diperoleh saat di dalam kelas.

Kuis pada penelitian ini dilaksanakan pada dini hari (02.30 s.d. 04.00), waktu yang paling tepat untuk belajar. Bahkan disebutkan bahwa daya serap materi belajar bisa mencapai $90 \%$ s.d. $100 \%$ (Kisworo, 2014). Waktu inilah yang coba akan dioptimalkan pada penelitian ini. Tempatnya pun di rumah masing-masing.

\section{Blackberry Messenger}

BlackBerry Messenger atau yang lebih dikenal dengan BBM adalah aplikasi pengiriman pesan singkat yang dibuat secara khusus untuk pengguna perangkat BlacBerry (Febrianti, 2015). Namun seiring berjalannya waktu, aplikasi BBM kini bisa berjalan di hampir semua platform, tak terkecuali Android dan iOS. BBM merupakan salah satu sarana komunikasi paling tersohor dewasa ini (Windujati, 2015).

BBM sangat menjunjung tinggi keprivasian para penggunanya. Bahkan penyedia layanan internetpun (provider) tak bisa mengakses pesan menggunakan BBM. Hal inilah yang menjadi daya tarik tersendiri dari aplikasi ini. Selain itu BBM juga mempunyai akses yang cepat karena mempunyai server tersendiri (Hermawan, 2015).

Pesan dikirim melalui jaringan internet menggunakan sistem PIN unik BBM (Pradana, 2011). Setiap aplikasi BBM akan dihubungkan dengan PIN untuk bisa saling bertukar pesan maupun data. Pengguna BBM bisa mengirimkan file sampai ukuran $16 \mathrm{MB}$ secara realtime (Bla1ze, Februari).

Kuis sebagai Sarana Evaluasi Mahasiswa

Jika di sekolah menengah mengenal istilah ulangan harian, diperguruan tinggi mempunyai istilah lain, kuis (Saputra, Cyber Learning Unissula, 2011). Sama halnya dengan ulangan harian, kuis juga merupakan sarana untuk mengevaluasi ketercapaian tujuan pembelajaran (Hidayat, 2011). Menggunakan kuis inilah dosen bisa mengetahui apakah tujuan pembelajarannya sudah tercapai atau belum. Kuis bisanya diadakan pada akhir setiap topik pembahasan. Terdiri dari satu hingga tiga soal saja, namun soal sudah mencakup konsep topik pembahasan.

Kuis sangat dibutuhkan pada jurusan eksakta, karena cukup aneh jika pembelajaran sains diajarkan menggunakan metode presentasi di depan kelas.

\section{Waktu Belajar}

Ada banyak faktor yang mempengaruhi keberhasilan dalam belajar (Khafid, 2008). Mulai dari suasana, lingkungan, kondisi psikis, dan yang tak kalah pentingnya adalah waktu belajar.

Menurut J. Briggers (Muhibbin, 1995) waktu belajar pagi hari lebih efektif daripada belajar di waktu-waktu lainnya. Pagi di sini diartikan sebagai waktu jam pelajaran di sekolah (Pkl. 07.00 s.d. 11.00). Waktu yang optimal untuk belajar adalah tatkala dini hari (Kisworo, 2014). Karena daya serap otak bisa mencapai 90 s.d. 100\%. Saat dini hari, suasana amatlah tenang, udara terasa sejuk, dan otak kita dalam kondisi fres, karena baru beristirahat.

Tidak hanya itu, menurut ajaran Islam, waktu inilah waktu yang paling baik untuk berdoa (Misliyani, 2014), karena pada jam ini seluruh doa kita akan diijabah oleh sang Khalik.

\section{Gaya Belajar}

Gaya belajar setiap orang memang berbeda-beda. Gaya belajar merupakan modal belajar yang sangat penting (Sari, 2014). 
Sebagian orang bisa belajar dengan sangat baik hanya dengan melihat orang lain melakukannya. Macam gaya belajar antara lain Visual, auditorial, kinestetik (Nikmawati, 2014). Masing-masing orang mempunyai cara tersendiri yang sesuai dengan pribadinya.

Selain gaya belajar, cara belajar juga mempunyai peranan penting. Ada sebagian kalangan yang lebih suka belajar sambil duduk, sambil berbaring, bahkan ada yang suka belajar sembari mendengarkan musik. Cara belajar seperti ini tidak mungkin diperoleh dalam situasi formal dalam kelas.

\section{Metode Penelitian}

Penelitian ini merupakan penelitian studi lapangan, jenis penelitian ini adalah deskriptof kualitatif. Data yang diperoleh merupakan kata, kalimat, gambar, dan bukan dalam bentuk angka-angka.

Subjek pada penelitian ini adalah mahasiswa Pendidikan Fisika FKIP Universitas Ahmad Dahlan yang menempuh mata kuliah Fisika Matematika 1 Semester Gasal Tahun akademik 2015/2016. Mahasiswa telah memperoleh materi tentang deret fourier. Mahasiswa diberi soal kuis Fisika Matematika dengan topik Deret Fourier.

Kuis dikerjakan pada dini hari (Pkl. 03.00 s.d. $04.00 \mathrm{WIB}$ ). Sebelum mengerjakan soal, mahasiswa dihimbau untuk melaksanakan Sholat Tahajjud terlebih dahulu. Soal kuis diunggah melalui website. Hasil kuis dikirimkan ke dosen dalam bentuk gambar (foto) menggunakan aplikasi BBM.

\section{Hasil Penelitian dan Pembahasan}

Hasil penelitian menunjukan bahwa aplikasi BBM bisa dijadikan sarana untuk evaluasi mahasiswa. Bahkan lebih jauh lagi bisa dijadikan sebagai media pembelajaran dengan memanfaatkan fasilitas grup.

Penggunakan aplikasi BBM di sini lebih ditekankan pada fasilitas kecepatan transfer file-nya. Beda halnya dengan menulis dikertas, memindainya kemudian mengirimkannya menggunakan email, tentu ini akan menyusahkan mahasiswa. Dengan aplikasi BBM, transfer file akan lebih mudah dan cepat. Bahkan dalam waktu satu menit, lebih dari sepuluh mahasiswa berhasil mengirimkan hasil jawabannya.

Pemanfaatan waktu dini hari juga menunjukan hal yang positif. Sebelum mengerjakan kuis, siswa dihimbau untuk melaksanakan sholat malam terlebih dahulu, ini juga merupakan bagian dari pendidikan. Dengan sholat, dan berwudhu, maka rasa kantuk akan hilang, dan mahasiswa sial untuk belajar melali jalan mengerjakan soal kuis.

Aneka respon mahasiswa bisa dilihat dari update status BBM mereka. Ada respon yang positif, seperti yang ditunjukan pada gambar 1 .

$\begin{array}{ll}\text { sylvie aulia } & \text { Sel } 22.28 \\ \text { Status Baru } & \end{array}$

"sejarah pun mencatat kuis pertama yg dikerjakan dini hari."

$\begin{array}{ll}\text { Shella } & \text { Status Baru } \\ & \end{array}$

"Habis dzikir sama fismat saatnya tdur.. makasih bnget pak soalnya"

\begin{tabular}{|c|c|c|}
\hline 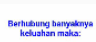 & Eng_Enggal & \\
\hline 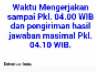 & Status Baru & Baru saja \\
\hline
\end{tabular}

"Terimakasih pak toni .. karenamu saya jadi bangun dini hari dan sedikit tepat waktu sholat subuh $\ddot{\theta}$ "

\section{Adetyas Ristiani}

Status Baru

Baru saja

"Ada hikmahnya dibalik kuis ini "saya sholat subuhnya gak kesiangan" $: *$ "

Mela Fitriana

Status Baru

2 menit yang lalu

"Kuis Fisika Matematika Alhamdulillah senam otak pagi ini $\theta$ "

Gambar 1. Posting status BBM mahasiswa dengan respon

positif

Ada pula respon yang mengungkapkan kekesalannya 


\begin{tabular}{|c|c|c|}
\hline \multicolumn{3}{|c|}{ Rina Novia } \\
\hline \multicolumn{3}{|c|}{ "Antara tidur dan tidak. Oh Kuis jam 03:00 } \\
\hline & $\begin{array}{l}\text { py } \\
\text { Status Baru }\end{array}$ & 3 menit yang lalu \\
\hline \multicolumn{3}{|c|}{ "Olah raga otak pagi-pagi mancapppssss } \\
\hline 1. 31 & $\begin{array}{l}\text { Hindaresmi } \\
\text { Status Baru }\end{array}$ & 1 menit yang lalu \\
\hline $\begin{array}{l}\text { "Duka m } \\
\text { gusti nu }\end{array}$ & $\begin{array}{l}\text { h naon lah ieu } \\
\text { Agung" }\end{array}$ & ngerjakn kuis \\
\hline
\end{tabular}

Gambar 2. Posting status BBM mahasiswa dengan negatif

Namun, apapun respon dari mahasiswa, nampaknya langkah ini merupakan awal untuk menerapkan pembiasaan yang baik kepada mahasiswa. Waktu dini hari yang mereka habisakan untuk tidur, bisa dimanfaatkan untuk hal yang lebih mulia, dengan belajar dan berdoa. Awal waktu memang akan terasa begitu berat, namun perlahan jika mahasiswa mampu konsisten, niscaya itu menjadi kebiasaan yang baik.

Mengerjakan kuis di rumah sesuai dengan cara belajar masing-masing juga merupakan hal yang positif. Mahasiswa bisa mengerjakan sesuai dengan apa yang mereka hendaki, tanpa harus ada batasan dalam ruang kelas. Namun tetap dalam koridor akademis (tidak saling contek), karena saat mengerjakan merupakan dini hari, dengan waktu yang singkat. Sehingga mahasiswa tidak punya wakttu untuk saling bertukan jawaban.

\section{KESIMPULAN}

Pemanfaatan BBM untuk sarana evaluasi mahasiswa merupakan contoh kecil penetrasi teknologi dalam dunia pendidikan. Transfer file yang sangat cepat, merupakan fasilitas yang bisa dimanfaatkan, untuk saling bertukar materi pelajaran (dalam penelitian ini untuk mengirimkan jawaban.

Melakukan evaluasi mahasiswa diwaktu dini hari, merupakan sarana pembiasaan kepada mahasiswa untuk bangun lebih awal, dan memanfaatkan waktu untuk hal yang lebih positif. Evaluasi dini hari juga merupakan sarana untuk "membebaskan" mahasiswa dalam kekangan ruang kelas saat mengerjakan soal. Sehingga diharapkan hasil yang diperoleh merupakan murni pemikiran mahasiswa, sesuai dengan kemampuannya.

\section{Daftar Pustaka}

Abadi, T. F. (2013). Simulasi Realitas Melalui Aplikasi Instant Messenger Dan Media Sosial di Smartphone (Studi Komunikasi Virtual Mahasiswa Pengguna Smartphone di Kota Magelang). Yogyakarta: Universitas Negeri Yogyakarta.

Bla1ze. (Februari, 2014). CrackBerry. Retrieved Maret 4, 2016, from CrackBerry:http://crackberry.com/6mbfile-size-transfer-limit-over-bbm-beaddressed-next-build

Fajrian. (2015, Maret). CNN Indonesia. Retrieved Maret 3, 2016, from CNN Indonesia:

http://www.cnnindonesia.com/teknolog i/20150327134253-188-

42341/demografi-pengguna-internetindonesia/

Febrianti, D. (2015). Gigilib UIN Surabaya. Retrieved Maret 6, 2016, from Gigilib UIN

Surabaya: http://digilib.uinsby.ac.id/2302/2/Bab\% 201.pdf

Hermawan, B. (2015). UPN Jatim Institutional Repository. Retrieved Maret 10, 2016, from UPN Jatim Institutional Repository:

http://eprints.upnjatim.ac.id/4649/1/file 1.pdf

Hestya, L. K. (2012, September). Technology Trendsetter. Retrieved Maret 5, 2016, from Technology Trendsetter: https://telset.id/51928/58-penggunasmartphone-dari-kalangan-remaja/

Hidayat, A. (2011). Rancang Bangun Sistem Kuis Online Adaptif sebagai Ekstensi Content Management System. Tesis, Universitas Dipenogoro, Semarang.

Khafid, M. (2008). Faktor - Faktor yang Mempengaruhi Ketuntasan Belajar Akuntansi : Motivasi Belajar. 
Lembaran Ilmu Kependidikan , 37 (1), 46-54.

Kisworo, D. A. (2014). Pengaruh Acara Televisi Terhadap Penggunaan Waktu Belajar Anak di Lingkungan II Kelurahan Beringin Jaya Kemiling Bandar Lampung. Lampung: Universitas Lampung.

Millward, S. (2014, Desember). Tech In Asia. Retrieved Maret 12, 2016, from Tech In Asia: https://id.techinasia.com/jumlahpengguna-smartphone-di-indonesia2018/

Misliyani. (2014). Retrieved from Kementrian Agama Sulawesi Selatan: https://sumsel.kemenag.go.id/file/file/A RTIKEL2014/arem1411025100.pdf

Muhibbin, S. (1995). Psikologi Pendidikan, suatu pendekatan baru. Bandung: Remaja Rosdakarya.

Nikmawati, I. S. (2014). Korelasi Gaya Belajar Siswa Kelas VII dengan Hasil Belajar Mata Pelajaran Sejarah Kebudayaan Islam di Sekolah Menengah Pertama (SMP) Islam Durenan Trenggalek. Skripsi, IAIN Tulungagung, Tulungagung.

NN. (2015, September). Wow Keren. Retrieved Maret 3, 2016, from Wow Keren: http://www.wowkeren.com/berita/tampi 1/00085483.html

Pradana, J. E. (2011). Sekolah Teknik Elektro dan Informatika (STEI) ITB. Retrieved Maret 29, 2016, from Sekolah Teknik Elektro dan Informatika (STEI) ITB: http://informatika.stei.itb.ac.id/ rinaldi. munir/Kriptografi/2010-

2011/Makalah1/Makalah1-IF3058-

Sem1-2010-2011-015.pdf

Saputra, I. B. (2011). Retrieved from Cyber Learning Unissula: http://cyberlearning.unissula.ac.id/file.p hp/1/modul_dosen.pdf

Saputra, I. B. (2011). Cyber Learning Unissula. Retrieved Maret 25, 2016, from Cyber
Learning Unissula: http://cyberlearning.unissula.ac.id/file.p hp/1/modul_dosen.pdf

Sari, A. K. (2014). Analisis Karakteristik Gaya Belajar Vak (Visual, Auditorial, Kinestetik) Mahasiswa Pendidikan Informatika Angkatan 2014. Jurnal Ilmiah Edutic , I (1), 1-12.

Widhyatmoko, D. (2011). Ponsel Lebih dari Sekedar Alat Komunikasi. Humaniora, 360-367.

Windujati, D. G. (2015, Juni). Jagat Review. Retrieved Maret 11, 2016, from Jagat Review:

http://www.jagatreview.com/2015/06/bl ackberry-messenger-masih-nomor-1-diindonesia/ 